\title{
KIA TĀWHARAUTIA TE MĀTAURANGA MĀORI: DECOLONISING THE INTELLECTUAL PROPERTY REGIME IN AOTEAROA NEW ZEALAND
}

\section{Eru Kapa-Kingi*}

\begin{abstract}
This article explores ways to decolonise aspects of the intellectual property system in Aotearoa New Zealand, primarily in respect of trade marks. It considers the seminal Wai 262 report of the Waitangi Tribunal and builds upon its findings and recommendations, while also offering new ideas of legal reform for protecting mātauranga Māori (Māori knowledge and expertise) from undue exploitation. This article also measures those ideas against the objectives and principles of the Agreement on Trade-Related Aspects of Intellectual Property Rights (TRIPS Agreement), as well as other internationally recognised rights. Essentially, this article maintains that for any mechanism to be effective in recognising and upholding the tino rangatiratanga (unqualified self-determination) of Màori over their own mätauranga, that mechanism must be founded upon the principles of tikanga Māori (Māori laws and customs), which is a notion crystallised within the Treaty of Waitangi/Te Tiriti o Waitangi. It must also find its own meaningful place in the law of New Zealand that surrounds us today. It is only in this way that the extractive and thereby oppressive binds of the western intellectual property regime can be unpicked and put aside and the tapu (high status and associated sanctity) of mätauranga can be upheld. These words are also an honouring of those who spent countless hours on the Wai 262 report. It is hoped this article gives new and much needed life to the issue of protecting mätauranga Māori, which is still as relevant today as it was then. Kei aku rangatira, kei aku tapaeru, kei aku whakaruakākā, tēnei e ngākau whakaiti nei (an acknowledgement of all those who took part in Wai 262).
\end{abstract}

* Te Aupōuri, Ngāti Kahu ki Whangaroa, Waikato, Te Whānau a Apanui. Submitted for the LLB (Honours) Degree, Faculty of Law, Victoria University of Wellington, 2019. 


\section{INTRODUCTION}

The preface of this article is the recognition that the global intellectual property system as it stands is a manifestation and continuation of the colonial agenda. This is because it allows for and encourages the thieving and appropriation of indigenous knowledge from often already colonised corners of society, which means those who have rights in that knowledge lose out and are further disenfranchised. This idea will be explained further in the initial stages of this article and it underpins the discussion throughout.

The overarching topic of this research addresses the following question: how can Aotearoa New Zealand's trade mark regime provide for stronger and more appropriate protection of mātauranga Māori (Māori knowledge and expertise), while still keeping in mind obligations under the Agreement on Trade-Related Aspects of Intellectual Property Rights (TRIPS Agreement)? ${ }^{1}$ This article will outline the recommendations already made by the Waitangi Tribunal in its Wai 262 report in respect of this question, but will ultimately expand on those recommendations and flesh out further practical, systemic changes which can be made to decolonise the intellectual property system in New Zealand. Initially, this discussion will focus on trade marks. However, this article will then consider other ways mātauranga Māori is used in Aotearoa and how those uses can be controlled and regulated in the interests of Māori. Similar issues experienced by other indigenous peoples in foreign jurisdictions will also be discussed and compared.

In building on the recommendations made by the Tribunal in respect of the intellectual property system, this article will propose and develop two alternative models of protecting mātauranga Māori in New Zealand. These are:

(i) adopting a mechanism of "cultural misappropriation" for the removal of trade marks, which would operate in addition to the offensiveness ground which already exists; and

(ii) creating a tikanga Māori-based system to protect against the misappropriation of mātauranga Māori.

Both proposals will also be assessed against the TRIPS Agreement. This article does not determine whether the mechanisms are in fact a violation of the TRIPS Agreement, but considers what might happen if an arguable violation was put forward. It then concludes that the objectives and principles of the TRIPS Agreement would encourage a favourable interpretation of those mechanisms. The relationship between the TRIPS Agreement and the United Nations Declaration on the Rights of

1 Marrakesh Agreement Establishing the World Trade Organization 1867 UNTS 3 (opened for signature 15 April 1994, entered into force 1 January 1995), Annex 1C (Agreement on Trade-Related Aspects of Intellectual Property Rights) [TRIPS Agreement]. 
Indigenous Peoples (UNDRIP) ${ }^{2}$ is also discussed to reinforce the argument for TRIPS consistency. After assessing those aspects, the article discusses the consistency of the proposed models with the right to freedom of expression in New Zealand, ${ }^{3}$ concluding that any encroachment on that right which may arise from these mechanisms would be justified in a free and democratic society.

The models will then be assessed and compared before addressing the question of whether they could run contemporaneously or whether they could be used as increments in a staged approach to improve mātauranga Māori protection in New Zealand. The idea of a growing third law, a mix of tikanga Māori law and Pākehā law, will also be discussed as a justification for implementing such a system.

Ultimately, this is an attempt to breathe new life into Wai 262, and to reinvigorate the surrounding debate about protecting mātauranga Māori, which has long been dormant. The issues still exist today and have not improved for Māori. Moreover, this article will provide an updated perspective on indigenous knowledge protection in an era which is essentially different to the one in which Wai 262 was written. There have been significant developments in the law around protecting and maintaining indigenous rights in New Zealand where there are strong Māori interests. This article claims that the intellectual property system should follow suit.

\section{DISCUSSION}

\section{A The Intellectual Property System: A Colonial Masterpiece}

Many indigenous nations have been subject to colonisation. Te iwi Māori (the Māori people) is no exception. One effect of this is that indigenous knowledge is misused by the coloniser. Examples of mātauranga Māori being misused within New Zealand and abroad are not difficult to come by. In early 20th century New Zealand many trade marks containing images of rangatira Māori (Māori leaders) were used on products such as alcohol and cigarettes, which is highly offensive, a fact the New Zealand Government now recognises. ${ }^{4}$ It is wrong from a Māori perspective to associate people with mana (power/authority)and therefore tapu (high status and associated sanctity) with kai (foodstuffs) because kai is an agent of noa (normal/absence of tapu), let alone products such as alcohol. But even besides that type of use, there is something instinctually wrong with corporations, such as Air New Zealand, misappropriating mātauranga Māori designs that do not belong to them without permission, and establishing extremely valuable brands with that mātauranga, without fully recognising its origin. ${ }^{5}$ There is a wrongdoing regardless of whether the trade mark used is overtly

2 United Nations Declaration on the Rights of Indigenous Peoples GA Res 61/295, A/RES/61/295 (2007) [UNDRIP].

3 New Zealand Bill of Rights Act 1990 [NZBORA], s 14.

4 New Zealand Intellectual Property Office "Practice guidelines" <www.iponz.govt.nz/about-ip/trade-marks〉.

5 See discussion below in Part II(C)(1) and Figure 1. 
offensive in the sense portrayed above. New Zealand's trade mark law now seems to allow this wider form of misappropriation. In other words, entities can benefit from a body of knowledge over which they would have no right, so long as that beneficial use is not overtly offensive.

Aroha Mead refers to this as being the "second wave of colonization" - grabbing what few resources Māori retained after the first wave of colonisation left Māori landless and marginalised. ${ }^{6}$ International corporations as well have seen fit to take Māori concepts and turn them into brands for their products without consultation. For example, the Danish company Lego, in creating and releasing its Bionicle series, utilised a myriad of Māori words for its characters, an action successfully opposed by Māori. ${ }^{7}$ Several indigenous Māori nations were offended by the liberal, culturally insensitive and trivialising use of their native language in the series of toys and films released by Lego and directly asked Lego to change its behaviour because the use was inappropriate and was without consultation or prior informed consent. ${ }^{8}$

This problem afflicts other indigenous nations. The National Football League (NFL) franchise the Washington Redskins is one example. The term "redskins" is a racial slur used against the indigenous peoples of America. ${ }^{9}$ That franchise has used this slur for its own branding and has established quite a reputation in the process. Although in 2020 it has stopped using that slur. There is also the case of a Chicago company which secured a trade mark over the word "aloha" and (ironically) sent cease and desist letters to Hawaiian institutions to stop them from using that word, an issue now being dealt with by the Council for Native Hawaiian Advancement. ${ }^{10}$

The unpermitted use of indigenous knowledge for economic benefit is a global phenomenon. It affects indigenous peoples all over. However, it did not just appear out of thin air, but has a deepseated history which lends itself to the oppression of minority cultures. Peter Drahos makes the following statement: ${ }^{11}$

6 Aroha Te Pareake Mead "Understanding Māori Intellectual Property Rights" (paper presented to the Inaugural Māori Legal Forum, Wellington, 2002) at 1.

7 Andrew Osborn "Maoris win Lego battle" The Guardian (online ed, London, 31 October 2001).

8 Wainohia Lum-ho "Exploitation of Polynesian Spiritual Imagery in the Toy Industry" (2013) 11 HOHONU 16 at 16.

9 Ian Shapira and Ann E Marimow "Washington Redskins win trademark fight over the team's name" The Washington Post (online ed, Washington, 29 June 2017).

10 Radio New Zealand "Restaurant accused of cultural appropriation by Hawaii group" (6 August 2018) <www.radionz.co.nz/international/pacific-news〉.

11 Peter Drahos "The Injustice of Intellectual Property" (2017) 110 Intellectual Property Forum: Journal of the Intellectual and Industrial Property Society of Australia and New Zealand 56 at 57. 
The globalisation of intellectual property that we are witnessing is part of a familiar colonial phenomenon.

... Underneath the moral rhetoric of intellectual property there lies an agenda of underdevelopment. It is all about protecting the knowledge and skills of the leaders of the pack.

Drahos articulates this idea further in highlighting that the intellectual property system is an "extractive property order" which allows one group to obtain assets belonging to a second group without any consent or compensation, a regime which is largely non-developmental for the second group in terms of economy. ${ }^{12} \mathrm{He}$ also states that if governments do nothing to address problems for indigenous peoples created by extractive property rights, there will be a continuing block on development and problems familiar to many indigenous peoples such as poverty and inequality will persist. ${ }^{13}$ The extractive property order approach underscores the introductory point that there is a colonial agenda behind the global intellectual property system. Parts of the global intellectual property system are essentially predicated on keeping indigenous peoples vulnerable by limiting their chances to develop economically. They also keep the colonial state (made up mostly of non-indigenous stakeholders) powerful by privileging its ability to exploit knowledge systems which do not belong to it, without much opportunity for the indigenous custodians of those knowledge systems to challenge it. This theory is central to the main thesis of this article. It is the broad problem which the proposed models seek to address.

Drahos also labels common justifications for the intellectual property system as "moral rhetoric". ${ }^{14} \mathrm{He}$ is referring to the oft-repeated theories of innovation through incentivisation and ensuring product origin. ${ }^{15}$ These intellectual property theories do seem to hold some weight. However, the reality is that rights in intellectual property have come to provide the means to build economic powerhouses at the cost of indigenous welfare, and public welfare more broadly. The motivation to build individual economic wealth seems to have eclipsed the innovation theory, yet that theory is still used to cloak the underlying agenda of economic underdevelopment of indigenous people and the economic growth of business generally. Coca-Cola, for example, has a brand value estimated at USD 80.83 billion, ${ }^{16}$ a figure only made possible by exclusive rights provided through the intellectual property system. It is difficult to deny, in the face of these invaluable brands, the reality that one of the main motivations behind maintaining the strength of the intellectual property system is to protect the economic value of multibillion dollar companies such as Coca-Cola which have built empires on their brand names. These companies support the perpetuation of the intellectual property

12 Peter Drahos Intellectual Property, Indigenous People and their Knowledge (Cambridge University Press, Cambridge (UK), 2014) at 4.

13 At 11 .

14 See Drahos, above n 11, at 57.

15 TRIPS Agreement, above n 1; and Trade Marks Act 2002, s 5 definition of "certification trade mark".

16 Statista "Brand value of Coca-Cola 2006-2019" (9 August 2019) <www.statista.com/statistics>. 
system and also have the resources to do so. Indigenous peoples inevitably struggle to compete with or even challenge those companies if they misappropriate indigenous knowledge or use offensive branding, as illustrated by the Redskins example. ${ }^{17}$

Indeed, Susy Frankel observes that "globally cracks are developing and challenges to ever rising standards of intellectual property (IP) protection have begun to succeed". ${ }^{18}$ There is a growing realisation generally that the intellectual property system unduly favours powerful businesses as it has been used to "firm up their position and maximise profits for as long as is possible". ${ }^{19}$ This article hones in on the particular effects suffered by Māori due to a combination of both the extractive nature of the system, and the growth of "overprotection", ${ }^{20}$ emphasising the need to reform the intellectual property system to elevate the position of Māori economically. Māori should be provided equal opportunity to develop in this way.

Specifically, the New Zealand intellectual property system (as derived from the western system) unduly extracts value from mātauranga Māori for the economic gain of those who have no custodial rights in that mātauranga. This often leaves Māori disenfranchised and promotes the establishment of hugely valuable brands, such as the All Blacks. Another more specific example which articulates this argument is the All Blacks' use of the haka "Ka Mate". This is a haka which belongs to Ngāti Toa Rangatira and has contributed immensely to the All Blacks' unique branding by separating the franchise from others in the same sport. ${ }^{21}$ However, the All Blacks have never had to pay any financial recompense to Ngāti Toa Rangatira. This is because Ngāti Toa Rangatira could not claim that copyright still exists in the haka composition as the composer of that haka, Te Rauparaha, died more than 50 years ago. ${ }^{22}$ It is only recently that Ngāti Toa Rangatira have received formal recognition of their kaitiaki (custodian or protective) relationship with that haka through a statute negotiated as part of their historical Treaty of Waitangi claims with the Crown. ${ }^{23}$ However, this has not led to any economic benefit to Ngāti Toa Rangatira. The statute merely gives a right of attribution when the haka

17 Pro-Football, Inc v Blackhorse 112 F Supp 3d 439 (ED Va 2015).

18 Susy Frankel "It's raining carrots: the trajectory of increased intellectual property protection" in Gustavo Ghidini, Hanns Ullrich and Peter Drahos (eds) Kritika: Essays on Intellectual Property (Edward Elgar Publishing, Cheltenham (UK), 2017) vol 2159 at 161.

19 At 161 .

20 At 161.

$21100 \%$ Pure New Zealand "History of the All Black haka" <https://media.newzealand.com>

22 Copyright Act 1994, s 22(1).

23 Haka Ka Mate Attribution Act 2014, s 3. See also Treaty of Waitangi 1840. 
is used in public and any failure to attribute is only remediable by declaration. ${ }^{24}$ This exemplifies how the system disadvantages Māori in the protection of their own mātauranga and therefore contributes further to Māori economic impoverishment.

It was not too long ago in New Zealand that the colonial government legislated a ban on certain medical practices derived from mātauranga Māori, via the Tohunga Suppression Act 1907. Māmari Stephens describes this legislation as a way to "allay Pākehā fears about Māori attempts to claw back some of the political power and representation that had been lost to them over the previous decades of colonisation", ${ }^{25}$ to symbolically "reassert certainty and political dominance". ${ }^{26}$ This seems ironic given that now, mātauranga Māori has become extremely trendy in marketing as well as product creation. The difference in the early 1900s may have been the lack of understanding around rongoā Māori (Māori medicine) and therefore the inability to control and appropriate it. However, as time passed, not only did familiarity with mātauranga Māori grow, so did its misappropriation through a western system which was, and still is, alien to Māori ways of existence. The Tribunal in Wai 262 considered claimants' concerns in respect of a range of rongoā Māori resources (described by the Tribunal as "taonga species") such as mānuka and harakeke, noting specifically that the latter has been commercially exploited as an ingredient for skincare products and has even been investigated for its potential as a clothing fabric. ${ }^{27}$

It is important to understand this wider context before discussing the protection and regulation of mātauranga Māori. This not only recognises the superimposition of a system upon a culture which already had equally legitimate and more appropriate systems of maintaining knowledge, but also the fact that this foreign system is founded on an attempt to assert and maintain colonial power by disadvantaging those who belong to that culture. Those carefully crafted biases still exist within the intellectual property system today. For example, the longest place name in the world - which can be abbreviated to "Taumatawhakatangihanga" - is a name over which Ngāti Kere are kaitiaki or protectors, yet they have been unsuccessful in their attempts to secure intellectual property rights in the name to prevent its commercial use. ${ }^{28}$ This shows again that intellectual property rights are mostly unsuited to serving Māori interests.

24 Haka Ka Mate Attribution Act 2014, ss 9-11. For a discussion of this issue see Izzy Tekaumārua Wilson "The Misappropriation of the Haka: Are the Current Legal Protections around Mātauranga Māori in Aotearoa New Zealand Sufficient?" (2020) 51 VUWLR 523, also in this special issue.

25 Māmari Stephens "A Return to the Tohunga Suppression Act 1907" (2001) 32 VUWLR 437 at 438.

26 At 438

27 Waitangi Tribunal Ko Aotearoa Tēnei: A Report into Claims Concerning New Zealand Law and Policy Māori Culture Identity: Te Taumata Tuatahi (Wai 262, 2011) [Ko Aotearoa Tēnei: Te Taumata Tuatahi] at 66-67.

28 At 30 . 


\section{B Reawakening Wai 262}

In its Wai 262 report, the Waitangi Tribunal identified (among many other things) the fundamental disconnect between the intellectual property system and the notion of protecting mātauranga Māori in a manner consistent with Māori laws and principles. The essential question which the Tribunal addressed was whether "the gap" between New Zealand's intellectual property law and mātauranga Māori can (and even should) be bridged. ${ }^{29}$ The Tribunal stated in clear terms that the rights of Māori in manifestations of mātauranga Māori are derived from the promise in art 2 of the Treaty of Waitangi/Te Tiriti o Waitangi, the founding constitutional document of New Zealand, which guarantees tino rangatiratanga (absolute authority) over many things, including taonga (treasures or things that hold some type of value - more than monetary value). ${ }^{30}$

This highlights the constitutional importance of protecting mātauranga Māori. This is an obligation which all citizens of New Zealand ought to bear because that citizenship was only ever made possible through the Treaty. The Treaty allowed for the joining of Māori and non-Māori in Aotearoa in exchange for the protection of taonga Māori (amongst other things). ${ }^{31}$ Dr Carwyn Jones states that "[a]t its heart the treaty provides a framework for the relationship between Māori and the New Zealand government"; something which "informs discussions in New Zealand public life that relate to constitutional powers and limitations". ${ }^{32}$ The Treaty is therefore integral to any discussion around protecting mātauranga Māori.

The Tribunal made several recommendations in respect of the New Zealand intellectual property system. Those most relevant to this article have to do with amending the trade mark regime. However, the nomenclature the Tribunal created to identify types of mātauranga Māori works must first be explained. The Tribunal labelled one category "taonga works" - these are essentially manifestations of mātauranga Māori which have a deep whakapapa (history/genealogy) and a relationship with a kaitiaki (a custodian/protector). ${ }^{33}$ The second category formed was "taonga-derived works" - the Tribunal described this as the more amorphous category, which includes works which have a Māori element in them but which might also be mixed with non-Māori elements, making them so generic that they have no whakapapa or associated kaitiaki. ${ }^{34}$ The Tribunal also stated that no person, even

29 At [1.5.1].

30 At [1.5.2(1)]

31 Treaty of Waitangi, arts 1 and 2.

32 Carwyn Jones New Treaty, New Tradition: Reconciling New Zealand and Māori Law (UBC Press, Vancouver, 2016) at 7.

33 Ko Aotearoa Tènei: Te Taumata Tuatahi, above n 27, at [1.5.2(1)].

34 At [1.5.2(2)] 
an owner of intellectual property, should be allowed to use mātauranga Māori in a derogatory or offensive manner, regardless of the category that work belongs to. ${ }^{35}$

In respect of the protection of taonga works (which can be infringed by certain trade marks), the Tribunal recommended a commission be established to replace the Māori Trade Marks Advisory Committee currently operating in the Intellectual Property Office of New Zealand (IPONZ). This commission would hear and adjudicate complaints by kaitiaki for the commercial exploitation of their taonga works, particularly where this occurred without consultation of kaitiaki. The commission would have the power to make decisions binding on all parties. ${ }^{36}$ The Tribunal further recommended that this commission be allowed to facilitate best practice around the use of mātauranga Māori by publishing clear and comprehensive guidelines for traders in New Zealand, as well as exercising an administrative function which would involve creating and maintaining a register of kaitiaki interests. ${ }^{37}$ These functions are explained further in the following section.

\section{Adjudicative function}

The Waitangi Tribunal recommended that the commission be empowered to receive objections from anyone alleging derogatory or offensive use of mātauranga Māori in the public domain (being either taonga or taonga-derived works) and to decide the best way forward to remedy those objections. ${ }^{38}$ Also, that the commission be able to receive objections about the commercial exploitation of taonga works (even in the absence of derogatory or offensive use), on the grounds that there was no consultation with the kaitiaki of that taonga. The Tribunal suggested that the commission may even require consent from that kaitiaki where the degree of the kaitiaki interest deems this appropriate. ${ }^{39}$ Māori claimants ought to have standing to object to trade marks purely on the grounds that there is misappropriation of mātauranga Māori, even if the use in itself is not necessarily offensive. This recommendation ought to be maintained.

The Tribunal puts forward an effective model. However, some warnings should be expressed. History suggests that bodies granted powers to consider and determine Māori interests through adjudication fall into a more adversarial process, which is not entirely appropriate when considering applying tikanga Māori. An example of this happening is the Waitangi Tribunal itself. Professor Richard Boast remarks that acknowledgements of the Tribunal process as uniquely Māori are

35 Waitangi Tribunal Ko Aotearoa Tēnei: A Report into Claims Concerning New Zealand Law and Policy Māori Culture Identity: Te Taumata Tuarua (Wai 262, 2011) vol 1 [Ko Aotearoa Tēnei: Te Taumata Tuarua vol 1] at 87 .

36 Ko Aotearoa Tēnei: Te Taumata Tuatahi, above n 27, at [1.8].

37 At [1.8]

38 Ko Aotearoa Ténei: Te Taumata Tuarua vol 1, above n 35, at 93.

39 At 94 
"overcolour[ed]" and that the process in the Tribunal is essentially normal tribunal procedure, only more "formal and judicialised". ${ }^{40}$ The fact that hearings are held on marae and te reo Māori is sometimes used would not change the fact that the process being followed is derived from western law. My own personal observation of Waitangi Tribunal hearings is that they are dominated by lawyers and the debates can get quite heated as counsel for both sides duel for the Tribunal members' attention. This article suggests measures should be taken to avoid any new commission's process becoming too court-like.

Now, the Wai 262 Tribunal deliberately left that process open - presumably, because of many of the Tribunal's comments (particularly in its recognition of the need to have experts in tikanga Māori as part of the commission), that the commission should be free to create its process independently, taking full account of the views of te iwi Māori. ${ }^{41}$ This article merely makes express that it is important that any model used be genuinely and fundamentally Māori in its framework and process. This commission would presumably need to interpret and apply to specific contexts matters quintessential to tikanga Māori such as kaitiakitanga, whakapapa, whanaungatanga (maintenance of kin relationships), tapu and mana. There is a risk that this might occur in an overly adversarial forum which is alien to tikanga Māori. This risks even further the misapplication of tikanga Māori matters and would not serve to fill that gap which the Tribunal points to between Māori and western notions of regulating knowledge.

\section{Administrative function}

The commission's administrative function involves the maintenance of a kaitiaki interests register to allow easy access to information regarding particular interests in taonga works, which would be created and maintained by the commission. ${ }^{42}$ The Waitangi Tribunal saw this as having value in giving fair warning to the world and also bolstering any claim made if an interest does arise, as the register can be used as evidence of an existing interest. ${ }^{43}$ However, the Tribunal did not want this to be a compulsory regime whereby all kaitiaki had to register their interests for them to be recognised; this was out of respect for the fact that some kaitiaki may prefer to keep their interests private. ${ }^{44}$

This article adds that a register, despite its pragmatic benefits, should be treated with caution. Mātauranga Māori is imbued with (to differing degrees) the forces of mana and tapu. There is risk of degrading this mana and tapu through exposing it on a register for the general public to poke and prod

40 Richard Boast "The Waitangi Tribunal: 'Conscience of the Nation', or Just Another Court?" (1993) 16 UNSWLJ 223 at 233-234.

41 Ko Aotearoa Tēnei: Te Taumata Tuatahi, above n 27, at 52-55.

42 Ko Aotearoa Tēnei: Te Taumata Tuarua vol 1, above n 35, at 95.

43 At 95.

44 At 95 . 
at. The Tribunal explicitly outlines the register's non-compulsory nature in recognition of the sensitivity of mātauranga Māori. ${ }^{45}$ However, in practice there is at least a risk that a registration system might become de facto compulsory. This is because claims by kaitiaki might, in reality, be stronger if their interests are registered. Kaitiaki might then in some cases feel forced to participate in the system and register their interests. This is difficult to assess in the absence of empirical evidence as to the operations of such a commission. Yet, this article still suggests that the idea of public registration sits uncomfortably with the mana and tapu associated with some mātauranga Māori, which emphasises the difficulty in remedying the fundamental disconnects between western models and any other models based solely on the values and principles of tikanga Māori.

This article does not discount the general value of accessibility to certain information through a register, but suggests limiting accessibility to registered interests to an absolute necessity (for example, only to trade mark applicants and decision-makers on a case-by-case basis). This limitation would more appropriately align the registration system with tikanga Māori values and principles. This might well present difficulties if there is third-party opposition, however, there could also be exceptions put in place to reveal registered interests to the extent necessary to a third party, if that third party is shown to have a significant interest in the matter.

\section{Facilitative function}

The commission's facilitative function, as the Waitangi Tribunal outlined, would require it to proactively provide general information, guidelines and assistance to the public around the sensitivities of using mātauranga Māori and the appropriate points of contact for any possible use of mātauranga Māori. ${ }^{46}$ The Tribunal envisaged the commission naturally becoming "the first port of call" for those seeking guidance on their own practices in respect of trade marks which might infringe mātauranga Māori.

In most cases, prevention is probably the best policy and this function would certainly serve to prevent misappropriation of mātauranga Māori. In fact, the IPONZ has already released a number of guidelines on the use of mātauranga Māori. ${ }^{47}$ It might be said that those guidelines have been helpful in educating the general public around mātauranga Māori issues. I would only add that it ought to be stressed explicitly (though evident in the Tribunal's comment that the commission would only be the first port of call) that the commission cannot be seen as the spokesperson for all Māori in Aotearoa. There are varying interests across all sectors of Māoridom; no one entity could ever represent or encapsulate those interests and nor should it be expected to do so (and it is accepted that this diversity in Māori opinion also points to a need for some type of adjudicative system where issues can be

45 Ko Aotearoa Tēnei: Te Taumata Tuatahi, above n 27, at 54.

46 Ko Aotearoa Tènei: Te Taumata Tuarua vol 1, above n 35, at 94-95.

47 See for example New Zealand Intellectual Property Office, above n 4. 
resolved by parties with differing interests in light of different evidence, as referred to above). It should also be made plain that the commission can and should reach out to find appropriate representatives when necessary to alleviate its inability to consider all Māori interests in all cases. These suggestions, which build upon the Wai 262 proposed commission, will be incorporated below in discussing a tikanga Māori system for protecting mātauranga Māori.

The New Zealand Government is yet to give full effect to the Wai 262 recommendations in respect of mātauranga Māori. It seems unlikely this will occur any time soon given the Tribunal published this report almost a decade ago. However, at the time of writing, the Government is starting to put in place Wai 262: Te Pae Tawhiti, described as a "whole-of-government approach to address the issues raised by the vast Wai 262 claim". 48 The Government is yet to meaningfully consider the Tribunal's recommendations, resulting in the continual misuse of mātauranga in all spheres of intellectual property. This highlights the urgency New Zealand now faces in creating effective and appropriate protections before there is almost nothing left to protect, or worth protecting.

As stated in the introduction, this article builds on the recommendations made by the Tribunal in respect of the intellectual property system and further develops other alternative protections for mātauranga Māori that could be used today. Practical solutions in addition to the recommendations are important, as is the global context.

\section{Alternative Models: Addressing the Extractive Property System}

Genuinely indigenous solutions should be put forward for indigenous problems. By that it is meant solutions which are predicated on Māori values and Māori systems of resolving issues. First and foremost, the label "commission" should be changed. It is a problematic term in itself because its starting point is in western governance. ${ }^{49}$ As opposed to attaching aspects of tikanga Māori to an essentially western mode of power, which risks ineffectiveness in practice, this article suggests instead using the name "rūnanga" 50 to endow the body with the mana to manage the use of mātauranga Māori (this is expanded on further below). This may seem minor but will nonetheless contribute to forming a solution which is thoroughly and unapologetically Māori. The Tribunal in Wai 262 deliberately left the issue open for Māori to engage in the conversation about how a Māori commission would operate and what it might look like.

Authentic indigenous solutions can still operate in the wider non-indigenous system. How is this to be achieved? First, by considering alternative models which are primarily and expressly based on

48 Te Puni Kōkiri Ministry of Māori Development "Te Pae Tawhiti: Wai 262" (21 October 2020) <www.tpk.govt.nz>.

49 See generally Commissions of Inquiry Act 1908.

50 To discuss in assembly (verb) or an assembly (noun). Traditionally used to describe groups within iwi or hapū which would come together to discuss and resolve issues of concern to the wider community. 
whakaaro Māori or Māori modes of thinking. Second, it is also important to appreciate the value of some western ideas of knowledge regulation and innovate ways of merging the two appropriately. The aim should be to reconcile the gaps posed by the fundamental differences between indigenous and western systems of knowledge protection. This means compromise in respect of what a new system might look like while still maintaining that the essence of Māoritanga (Māori-ness) ought to be immovable. To use the words of Aroha Mead: ${ }^{51}$

We should take as a given therefore that intellectual property laws are not perfect in their current form [for] Maori, but, nor are they of no use or relevance to Maori. In my opinion, we should put more effort into enabling dialogue around the middle ground rather than continue with the paralysis and fear at the two end points of the spectrum.

Of course, this is easier said than done (as the length of and time to write Wai 262 suggests) and, to reiterate, there needs to be compromise to reach a solution. However, there must be greater effort to privilege a Māori perspective and Māori law in protecting mātauranga Māori to find a middle ground. Currently, the system mostly silences the voice of Māori. The following discussions forge more progressive reforms in respect of the intellectual property system in New Zealand, so that voice can be heard. There is no denying that the intellectual property system, as inherited from the law of our parent country, England, and indeed adopted by states across the world, has set it roots quite deeply. States have adhered to the system for a very long time. This means that any significant changes such as the ones this article proposes might seem far-fetched or unrealistic. However, as time goes by, attitudes shift and things which may seem unrealistic today may be the norm tomorrow.

The models proposed in this article are focussed on reconciliation. This means finding, as Mead describes above ${ }^{52}$ a "middle ground" between Māori and western systems to achieve coexistence and genuine partnership. The first proposal is more conservative in that it is a relatively minor amendment to the existing law and its effects would be limited to the trade mark regime. The second proposal is more radical in that it theorises a rūnanga tasked with the protection of mātauranga Māori through tikanga Māori (an adaptation of the Wai 262 commission) and that the ambit of the rūnanga would not be so limited to the use of trade marks. The rūnanga would focus primarily on protecting mātauranga Māori, in whatever way that may be used, through tikanga Māori. These two proposals are outlined and explained further below.

\section{Cultural misappropriation mechanism}

The cultural misappropriation mechanism is envisaged as a layer of protection over and above the mechanism of offensiveness which currently exists in New Zealand. ${ }^{53}$ This new standard would mean

51 Mead, above $\mathrm{n} 6$, at 2 .

52 At 2 .

53 Trade Marks Act, s 17(1)(c). 
that claimants could challenge the use of an aspect of mātauranga Māori on the grounds of misappropriation and not be limited to claims of offensive use. The term "misappropriation" itself would require some definition to clarify the scope of this protection mechanism. The legal meaning this article proposes is:

When either an applicant for trade mark registration or a trade mark holder uses any form of cultural or indigenous knowledge without providing recognition or recompense to, or gaining consent from, those who are custodians of that knowledge.

This definition of misappropriation is appropriate because it more precisely captures the misuse of mātauranga Māori due to the absence of recognition and consent, which might not fall into the net of offensiveness.

This would be one way of giving practical effect to some of the Wai 262 recommendations around kaitiaki challenging the use of mātauranga Māori by those who do not have a kaitiaki interest and have not consulted with kaitiaki. Additionally, this would appropriately widen the protection of mātauranga Māori from harm and unjust exploitation through trade marks and be more in line with the tikanga Māori principle of utu or reciprocity. How are these tikanga Māori principles relevant here? The Waitangi Tribunal in Wai 262 stated clearly that the protection of mātauranga Māori is embodied in art 2 of the Treaty, determining that mātauranga Māori is a taonga which deserves protection. ${ }^{54}$ For some, this might not necessarily mean that tikanga Māori is the appropriate means of protection for that mātauranga. However, Justice Williams, in his extrajudicial writing, has observed that Māori customary law or tikanga makes up "the norms that are encapsulated in the concept of tino rangatiratanga (self-determination in modern English) retained to Māori by Article 2 of the Treaty [over their taonga]", which he thinks is more conceptually sound than saying that tikanga also falls within the concept of taonga. 55 The Treaty and tikanga Māori actually go hand in hand in the protection of mātauranga Māori. The two concepts are inextricably linked.

Currently, objectors to trade marks on the ground of offensiveness must rely on s 17(1)(c) of the Trade Marks Act 2002. This section states that the Trade Marks Commissioner must not register as a trade mark or part of a trade mark any matter where the use or registration of that matter would be likely to offend a significant section of the community (which includes Māori). The Commissioner's decision is a matter of his or her own discretion based on the criteria in the Trade Marks Act. The Commissioner can take advice from and read the guidelines of the Māori Advisory Committee where there are issues concerning Māori. The Committee advises the Commissioner whether the use of a sign or mark would be offensive to Māori. ${ }^{56}$ Though the Commissioner is not strictly bound by the

54 Ko Aotearoa Tēnei: Te Taumata Tuatahi, above n 27, at 43-44.

55 Joseph Williams "Lex Aotearoa: An Heroic Attempt to Map the Māori Dimension in Modern New Zealand Law" (2013) 21 Waikato L Rev 1 at 9.

56 Trade Marks Act, s 178. 
Advisory Committee, the advice of the Committee has always been followed because there is an absolute prohibition on marks that are offensive to Māori, which in practice means that the Commissioner should not derogate from a recommendation unless there is counterevidence from other Māori. ${ }^{57}$ Even considering the role of that Committee, proving that the use of a mark would be offensive to Māori as a "significant section of the community" 58 could be difficult, either on a legal or factual basis. This is especially so when trade marks do not contain aspects which are overtly or explicitly offensive to Māori (for example, the Air New Zealand koru, as pictured on the following page). There remains a wider wrong (more of a sense of unjust exploitation) experienced by Māori when mātauranga Māori is used by non-Māori who have not stepped through any sort of consultative or compensatory process, even if that use is well-meaning, plain and inoffensive.

The current grounds for refusing trade marks in New Zealand do not seem to capture this wider wrong of misappropriation. The examples of offensive use which the IPONZ has published on its website to notify the public as to what would and would not be acceptable for trade mark registration, include the face of a rangatira in a trade mark sign which is associated with food products (already referred to above, also pictured below in Figure 1). ${ }^{59}$ Obviously, this is offensive to Māori because there is an image of a person of high rank being used to sell products which are eaten by a person, which inappropriately mixes the tikanga Māori forces of mana, tapu and noa. That same type of offensiveness would arise if a trade mark contained racial slurs which are derogatory of Māori. However, what about trade marks created by non-Māori that do not amount to offensiveness through insensitive or discriminatory use? There is an argument that s 17 can be interpreted more widely, so as to include the notion of cultural misappropriation, proving any reform redundant. However, it is unclear how broadly the inquiries of the Advisory Committee can be, particularly whether it can consider situations where it is harder to articulate offensiveness because it is not as overt as the examples outlined above.

Take the following scenario. A company owned and operated by non-Māori might want to utilise a particular kōwhaiwhai (traditional Māori painting) pattern in a trade mark for its product. That pattern is derived from a particular hapu in a specific region, a pattern which is generally known amongst Māori artists to belong to that hapū due to the rich and specific history associated with the pattern and the hapū. That company is also aware of that hapū's interests in the pattern but nonetheless decides it wants to use that pattern in a sign to sell its products. Those products are not illicit products or considered in any other way inappropriate to associate with the pattern, and there are no racial slurs or any offensive terms used in the sign in association with the pattern. However, that hapu was not consulted, nor promised any payment prior to the company deciding to use that pattern in its trade

57 Jessica C Lai "Māori Traditional Knowledge and New Zealand Patent Law: The 2013 Act and the Dawn of a New Era?" (2014) 17 J World Intellect Prop 34 at 39.

58 Trade Marks Act, s 17(1)(c).

59 New Zealand Intellectual Property Office, above n 4. 
mark application. There are at least two reasons why it might be difficult for that hapu to make a case for the refusal of that trade mark application under the current law. First, it would be difficult for that hapu to make a case for offensiveness in considering the sign and the way in which it has been used to promote the products. This is because there is nothing up front that jumps out as being offensive in the same way the examples used by the IPONZ do. Here, there is a more general sense of frustration which stems from the underlying wrong in that company's use of a design derived from a certain hapū's corpus of mātauranga Māori without any consultation or consent. Second, in these specific circumstances the fact that this particular hapu is offended (assuming this is made out) may not equate to a finding that all Māori and therefore a "significant section of the community" would be offended, as required under s 17(1)(c). This is because that hapū might only make up a small part of the Māori populace and an even smaller part of the general New Zealand populace.

It seems unclear whether the current law in New Zealand surrounding trade mark registration can be used to block the misappropriation of mātauranga Māori in the absence of a more overt and widely offensive use. This is not consistent with the interpretation of art 2 of the Treaty discussed above . The following images in Figure 1 also illustrate the point above. ${ }^{60}$ The one on the left would likely be easier to challenge on the grounds of offensiveness than the one on the right.

Figure 1.
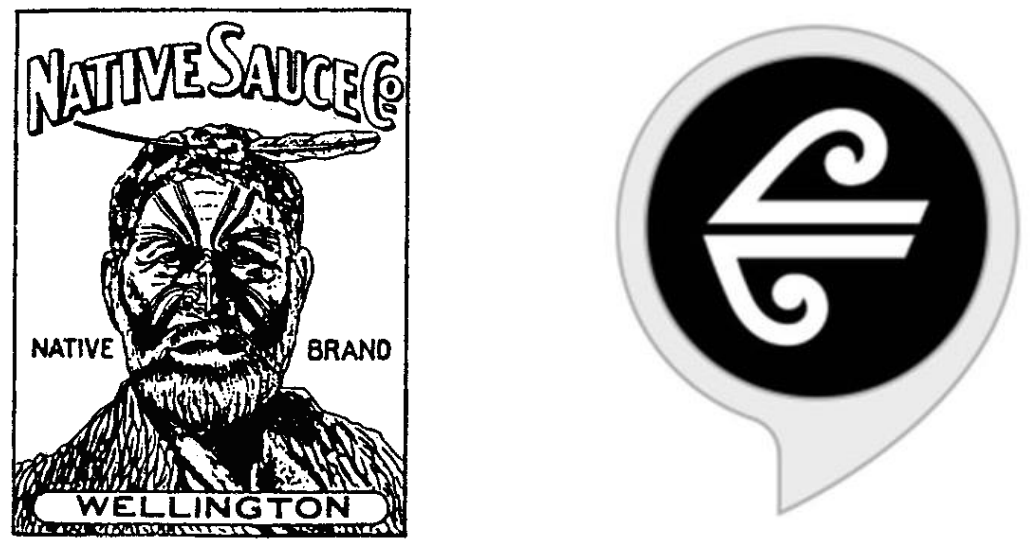

It is easier to articulate the offensiveness of the image on the left because, as stated above, the image of a rangatira is being used inappropriately in association with the word "sauce", which is a food and therefore should not be associated with someone of high mana. Also, one could also argue the word "native" has come to be used as a derogatory term against Māori which adds to the

60 New Zealand Intellectual Property Office, above n 4. 
offensiveness. ${ }^{61}$ However, the image on the right of the Air New Zealand logo could not be challenged on the grounds of offensiveness. There is nothing about the physical aspects of the image itself which can help articulate an element of offensiveness. However, it might still be frustrating that entities such as Air New Zealand have been able to build invaluable branding by misappropriating designs from mātauranga Māori without any acknowledgement of, or payment towards, Māori people. As it stands, though, it seems such use cannot be prevented and might even be a taonga-derived work, as the Tribunal described works without identifiable kaitiaki. This presents a gap in New Zealand's trade mark law.

To address this particular gap in the law, this article proposes a change in the form of a new ground to refuse trade marks, a ground of cultural misappropriation. To put this change simply, a claimant would not have to say "this is offensive to te iwi Māori because $\mathrm{x}, \mathrm{y}$ and z", but only "this is derived from mātauranga Māori, the applicants have not consulted any kaitiaki Māori or paid any compensation for its use, and therefore it should be rejected/removed because it amounts to cultural misappropriation". This might be more workable in some cases where it is harder to articulate a sufficient level of offensiveness as well as prove that level of offence would be felt by Māori as a "significant section of the community". 62

It seems most likely that gathering evidence to prove an element of mātauranga Māori in a trade mark is being used and that there has been no consultation, would be easier in some cases than proving a level of offence experienced by a significant sector of the community.

This new ground to refuse or remove a trade mark, in terms of legislative process, would not be difficult to implement. It could take the form of an amendment to s 17 of the Trade Marks Act as a new absolute ground for refusing a trade mark. This would also require inserting the definition of "cultural misappropriation" (as outlined above) into the interpretation section, though this would also be relatively simple. It is worth noting that "offensive" is not defined anywhere in the Trade Marks Act, which might suggest there would be no need to define cultural misappropriation. However, this article recommends that cultural misappropriation should be defined because it is likely a new and unfamiliar legal standard with very little existing judicial or legislative guidance. All this is not to say, however, that such a reform would be without political difficulty. Political parties might struggle to push this onto the legislative agenda, but in any case, making cultural misappropriation an absolute ground to refuse trade marks would show the importance of having better measures of protection for mātauranga Māori. This would also be a positive step towards fulfilling the Crown's duties under the Treaty. Further, as alluded to above, it is better aligned with the tikanga Māori principle of utu

61 I note here that this image was actually removed under the predecessor of the the Trade Marks Act on the grounds of "morality" which suggests the current Act has a broader protection against offensive trade marks.

62 Trade Marks Act, s 17(1)(c). 
(reciprocity) which is based on fairness and restoring social equilibrium by ensuring sources of knowledge are duly recognised, consulted and paid in kind, which prevents upsetting that equilibrium.

This approach does have some limitations. It can hardly be described as an alternative model. It still operates inside and therefore in accordance with the principles of the New Zealand intellectual property system. It does not go far enough to dismantle the extractive property system, nor does it provide a wide enough protection for mātauranga Māori so that it does not fall victim to that system. This model also would not fully discharge the Crown's obligations under the Treaty to provide for tino rangatiratanga over mātauranga Māori because the power to decide trade mark objections would still be vested in a non-Māori entity and exercised within a western system. This does not amount to tino rangatiratanga or self-determination. This model also does not fully recognise the sustaining and inseparable relationship between mātauranga Māori and tikanga Māori as tikanga Māori is not central to it, it is only partially upheld as a coincidence of its operation. Some academics recognise that there are some intellectual property mechanisms which coincidentally can be used to benefit indigenous interests (such as collective marks, as well as bans on offensive and deceptive use) yet conclude those mechanisms cannot provide comprehensive protection. ${ }^{63}$ The same argument applies here. Though a wider protection in respect of trade marks containing mātauranga Māori, this mechanism is not an allinclusive protection.

The other gaping hole that exists is that any marks used in trade which are offensive or deceptive in any sense by parties not seeking a registration for those marks are effectively out of reach to the trade mark regime and can be freely used without having to answer to any authority. ${ }^{64}$ This model here would not be immune to this issue and rests on the faulty assumption that all users of signs will seek registration of those signs. This is why the Tribunal in Wai 262 also made recommendations on matters outside trade mark registrations in outlining the functions of the commission, which reached beyond the trade mark regime. ${ }^{65}$

Refusing registration for cultural offensiveness would be generally consistent with the TRIPS Agreement. This is because art 15(2) of the TRIPS Agreement expressly empowers states to deny registration of a trade mark so long as the grounds for denial are consistent with the Paris Convention for the Protection of Industrial Property $1967 .{ }^{66}$ Article 6 quinquies $\mathrm{B}(3)$ of the Convention recognises

63 Daphne Zografos Johnsson "The Branding of Traditional Cultural Expressions: To Whose Benefit?" in Peter Drahos and Susy Frankel Indigenous Peoples' Innovation: Intellectual Property Pathways to Development (ANU Press, Canberra, 2012) 147 at 162.

64 At $162-163$.

65 Ko Aotearoa Tènei: Te Taumata Tuatahi, above n 27, at 52-54.

66 Paris Convention for the protection of industrial property of March 20, 1883, as revised at Brussels on December 14, 1900, at Washington on June 2, 1911, at The Hague on November 6, 1925, at London on June 2, 1934, at Lisbon on October 31, 1958, and at Stockholm on July 141967828 UNTS 305 (signed 14 July 1967, entered into force 26 April 1970). 
that states may deny or invalidate trade marks if those marks are "contrary to morality or public order and, in particular, of such a nature as to deceive the public". The Wai 262 Tribunal found that the art 2 Treaty promise of tino rangatiratanga over taonga was indeed a matter of public order. ${ }^{67}$

\section{Tikanga Māori system: "Te Rūnanga o te Mātauranga"}

The second reform proposed in this article would require a radical shift away from the current system of trade mark regulation (and indeed would implicate more than just the trade mark system) towards a new and separate system of knowledge regulation and protection founded upon tikanga Māori. However, this new system would still be largely aligned with and accepted by the current system, so that it has genuine effect on those systems and does not become something which operates outside of the sphere of influence. This system would aim not so much to dismantle the extractive nature of the intellectual property system but immunise mātauranga Māori by removing it from the claws of the extractive beast that is the intellectual property system.

In terms of what Te Rūnanga o te Mātauranga (Rūnanga) would look like and how it would operate in practice, this article draws on many of the Waitangi Tribunal's recommendations outlined above in respect of a new commission to regulate the unpermitted use of mātauranga Māori in signs. The Rūnanga would also have its own mana, separate from the IPONZ and would have greater powers to protect mātauranga Māori, in comparison to the merely advisory powers of the current Māori Advisory Committee within the IPONZ. Also, the mana of the Rūnanga would not be limited to dealing with trade mark issues. Building on Wai 262, this mana would be exercised solely for the protection of mātauranga Māori, framed independently to any intellectual property regimes, and would have influence over all public expressions of mātauranga Māori which breach tikanga Māori. However, it is recognised that inevitably, the practical implications of the Rūnanga's operations would require intersection between the mana of the Rūnanga and the intellectual property regime.

To be clear, the mana of the Rūnanga will only apply where mātauranga Māori is being used. Set out broadly, the criteria for a take (claim) and a kaikawe (claimant) would be:

(1) Any kaikawe must be Māori.

(2) Any take must relate to a takahanga (breach) of mātauranga Māori whereby that kaikawe has a whanaungatanga connection (a relational interest) (whereby "takahanga" and "whanaungatanga connection" ought to be construed broadly in accordance with tikanga Māori).

(3) The kaikawe must accept that matters will be addressed through tikanga Māori and therefore must have an understanding of it or relevant expertise to depend on.

If these criteria are made out, the Rūnanga will call a hui (meeting) between all interested parties whereby matters will be discussed in a non-adversarial environment. The question might be asked,

67 Ko Aotearoa Tēnei: Te Taumata Tuarua vol 1, above n 35, at 201. 
why would the infringing party attend this process? The Rūnanga would be given significant powers which could greatly affect all parties involved. So, if that party would like to have a say in the decision, it is likely they will attend.

It is also important to note the Rūnanga would be given the statutory authority to proactively investigate and pursue uses of mātauranga Māori without a take having been put forward in the first place, if convinced that use of a certain aspect of mātauranga Māori is inappropriate in respect of tikanga Māori. This would most likely affect more generally offensive uses because of the absence of a kaikawe with a direct interest in the mātauranga Māori in question. This would be different from the current law because the Rūnanga's mana would reach beyond the spaces of trade mark, copyright and patent, into the general use of mātauranga Māori. As the Rūnanga's power would not be limited to trade mark applications, it would have the power to regulate the use of signs which are not registered if offensive to Māori (similarly to the Wai 262 commission). This would fill the lacuna that exists in the current Māori Advisory Committee's limited remit to advise on applications to register potentially offensive signs. The Rūnanga would also be able to investigate and initiate its own take if it comes across any takahanga of tikanga Māori by public signs.

If the Rūnanga is convinced there has been a hē (wrong) in breach of the mana (importance) and/or tapu (sanctity) of an aspect of mātauranga Māori and the whanaungatanga relationship of the kaikawe, the Rūnanga will facilitate discussions further to derive an appropriate form of utu (recompense) to be borne by the committer of that hē. This utu could take the form of monetary compensation, banning any right to use that form of mātauranga, or any other appropriate mode of recompense. Ultimately, the utu should be decided in accordance with what the parties think is tika (correct/morally right) and have the goal of achieving ea (social balance). These are all of the relevant tikanga Māori principles the Rūnanga would utilise in regulating the use of mātauranga Māori. The Rūnanga itself would consist of a range of experts from different fields such as te reo Māori, tikanga Māori, toi Māori (art), and hītori Māori (history). Much like the Tribunal's committee model, the Rūnanga would also have an educational function to provide advice and education to the public on matters which touch in any way on mātauranga Māori as well as relevant information around tikanga Māori. This could be similar to how the IPONZ currently publishes practice guidelines on its website around the offensive use of mātauranga Māori. ${ }^{68}$

This article extends the Wai 262 recommendations in two ways. The first is that this body would not only operate independently from the IPONZ, it would also have a much higher degree of separation from the Government to ensure greater independence in decision-making and avoid any undue influence through the internal policies of any government agency. It is envisaged that the Rūnanga will be similarly situated to the Māori Land Court, being an independent body with binding powers and the authority to proactively investigate and address misuses of mātauranga Māori. This

68 New Zealand Intellectual Property Office, above n 4. 
higher degree of separation from the executive government would also mean that Māori claimants would have greater trust in the Rūnanga because it would be free from political influence. Also, giving the Rūnanga this greater mana means it can properly vindicate Māori concerns, better upholding the Crown's obligations under the Treaty.

Second, this article widens and fleshes out the tikanga Māori framework that the Tribunal offers as a means of protecting mātauranga Māori. In Wai 262 the Tribunal deliberately left the committee procedure open for te iwi Māori to determine. The Tribunal suggested, however, the concept of kaitiakitanga interests, which is a tikanga Māori concept, as a matter for the commission to determine. ${ }^{69}$ This article supports this recommendation of the Tribunal, yet encourages the express recognition and implementation of other tikanga Māori mechanisms (which are wider than, yet related to, the concept of kaitiakitanga) as the law which governs the use of mātauranga Māori in Aotearoa. This would allow the full force of tikanga Māori to permeate through the system, making that system more genuinely Māori.

Valmaine Toki outlines how tikanga Māori can be used to regulate mātauranga Māori. This is set out in the following: ${ }^{70}$

Tikanga Maori provides the framework to regulate, control and protect matauranga. For example, the matauranga related to a haka, composed for a particular battle, would be vested with the mana and tapu of the hapu that composed the haka. Similarly, the matauranga pertaining to the use of a particular plant for healing cuts and grazes would be vested in the hapu who developed that use. Mana and tapu would act as regulators securing their right to use that matauranga, while also imparting responsibility to protect that matauranga. In essence, they provide the rules as to when and how the matauranga should be used.

This quote provides some tangible examples of how tikanga Māori controls and manages the use of mātauranga Māori, specifically applying the concepts of mana and tapu. Another example of how these concepts may be employed in a trade mark context builds on the kōwhaiwhai example used above. The tapu of the mātauranga within that kōwhaiwhai pattern would be derived from the connections of that mātauranga to whakapapa or genealogical connections between past and present generations which gives it mana or a sense of importance. That mana and tapu would also be specifically vested in the hapū which guards that kōwhaiwhai pattern, as the descendants of its creator, having a shared whakapapa and therefore a whanaungatanga connection with that pattern.

Sir Hirini Moko-Mead used a three stage resolution process of take-utu-ea. ${ }^{71}$ In the example an unwarranted and inappropriate use of that pattern by another party would give rise to a take and then a decision as to the appropriate utu to be borne by the wrongdoing party, to achieve a state of ea.

69 Ko Aotearoa Tēnei: Te Taumata Tuatahi, above n 27, at 52-54.

70 Valmaine Toki "An Indigenous Right to Intellectual Property?" (2015) 4 IPQ 369 at 377 (footnotes omitted).

71 Hirini Moko Mead Tikanga Māori: Living by Māori Values (Huia Publishers, Wellington, 2016) at 30. 
During a hui between the company and the hapū (which would be the kaikawe here), the Rūnanga in giving effect to the tikanga Māori could encourage the parties to discuss whether the user should have sought consent to use the kōwhaiwhai pattern and whether there are any ways to resolve the take now. The user, after learning of the history of the pattern, might decide not to use it in respect of its tapu. Or, the user and hapū might agree to a payment scheme for its use and that the hapu be involved in the development of the trade mark to avoid its inappropriate use. This would hopefully lead to a consensus as to the appropriate way forward and preserve the relationship between the parties, getting to the stage of ea. If consensus cannot be reached and the company persists in trying to register the trade mark against the hapū's wishes, as a last resort the Rūnanga could instruct the Commissioner to refuse registration of the proposed trade mark sign which utilises the kōwhaiwhai pattern to make right the takahanga committed by the company and restore the balance of tika. This article suggests that these concepts be expressly weaved into this framework.

The principles which underpin tikanga Māori are inseparable from mātauranga Māori itself and therefore are the most appropriate form of regulation, as opposed to a system underpinned by values foreign to te ao Māori (the Māori world). It must also be noted that mātauranga Māori itself has a whakapapa connection to atua Māori (Māori gods). According to Māori cosmogenic beliefs, knowledge was gifted to humans by Tāne Te Wānanga, the God of Knowledge. He ventured to the highest of heavens to retrieve the three baskets of knowledge: Te Kete Tūari, Te Kete Tūatea and Te Kete Aronui, along with two stones called Nukutai and Rehutai. The baskets contained mātauranga and the stones were used to set Pae Tawhiti, or a distant horizon which would stand as a long-term goal in striving to develop knowledge. Some iwi believe that it was in fact Tāwhaki Nui a Hema who gathered those baskets of knowledge, and refer to those stones instead as Te Tūhōkainuku and Te Tūhōkairangi. However, the sole point is that mātauranga Māori is deeply imbued with cosmogenic story and therefore is highly tapu, with great mana. This is exemplified in these stories and the fact that tikanga Māori was used as a protector of mātauranga.

Drahos and Frankel recognise that intellectual property rights cannot on their own be the primary controller of indigenous knowledge systems because "indigenous innovation is driven by that complex web of relations that ... lies in the cosmological connectionism of indigenous peoples" and also embeds indigenous knowledge in land and places. ${ }^{72}$ Speaking in light of practices performed by the indigenous peoples of Australia, specifically those associated with Country, they show that the idea of people having a deeper connection with knowledge through cosmogenic belief resonates across many indigenous cultures. It is also an idea which is absent in western systems of knowledge governance. Any system which attempts to adequately and appropriately protect mātauranga Māori must embody the deeper cosmogenic beliefs of Māori and therefore tikanga Māori.

72 Peter Drahos and Susy Frankel "Indigenous Peoples' Innovation and Intellectual Property: The Issues" in Indigenous Peoples' Innovation: Intellectual Property Pathways to Development (ANU Press, Canberra, 2012) 1 at 23. 
Some mātauranga will be common to all Māori, but other mātauranga will be specific to a particular hapū or iwi. The source of the knowledge will dictate the relevant whanaungatanga connection and who will have a take within the Rūnanga's framework. This knowledge could be shared by the rightful custodian of the knowledge, thereby creating a relationship between the knowledge holders and the receivers who might use the knowledge. In those situations, there would obviously be no issue if that relationship is an amicable one and it would be unlikely that the Rūnanga would need to get involved. This would be preferable, and it is envisaged that the Rūnanga promote more robust consultation and consenting processes between Māori and non-Māori earlier on in the process of design and creation of any publication which utilises mātauranga Māori to avoid the Rūnanga having to intervene. This is similar to the facilitative function of Wai 262 outlined above. The educational function would further promote this ideal and lead to the public having greater respect for the value and importance of mātauranga as well as the Treaty partnership.

\section{Justified Encroachment on Freedom of Expression?}

The limitations and regulations outlined above affect how mātauranga is expressed in public, which may bring up the question of whether those limitations and regulations are an encroachment on the right to freedom of expression, and if so, whether such encroachment is justified. This is not dissimilar to the debate in the current intellectual property literature over whether intellectual property rights such as trade marks are a form of free speech and therefore any restrictions of trade marks based on content can violate freedom of expression principles. ${ }^{73}$ However, the inverse position is also true - that granting "over-zealous protection" of intellectual property rights such as trade marks can have a negative effect on other parties' rights (ie parties not being the holder of the trade mark right) to express anything which might be interpreted as unduly copying a trade mark. ${ }^{74}$ The reforms proposed above must be assessed for compliance with human rights protected in New Zealand. This assessment also rests upon the assumption that a claim could be made under s 14 of the New Zealand Bill of Rights Act 1990 (NZBORA) by way of s 3 of that Act. ${ }^{75}$

Freedom of expression is a fundamental human right guaranteed in the NZBORA, which embodies obligations pursuant to the United Nations' International Covenant on Civil and Political Rights (ICCPR), as noted in the Long Title of the NZBORA. Section 14 of the NZBORA states that "[e]veryone has the right to freedom of expression, including the freedom to seek, receive, and impart

73 Marc J Randazza "Freedom of Expression and Morality-Based Impediments to the Enforcement of Intellectual Property Rights" (2015) 16 Nev LJ 107 at 123.

74 At 122

75 There are grounds to argue that the Trade Mark Commission as well as the Rūnanga would at least fall under s 3(b) in light of the public function factors set out in the case of Ransfield $v$ Radio Network Ltd [2005] 1 NZLR 233 (HC) at [69], which would make the ohu susceptible to a claim under the NZBORA. It is also likely a prima facie breach of freedom of expression would be found in both instances given the wide scope of that right set out in Moonen v Film and Literature Board of Review [2000] 2 NZLR 9 (CA) at [15]. 
information and opinions of any kind in any form." However, no single right expressed in the NZBORA is absolute, as seen in a number of cases where it has been emphasised that individual freedoms are necessarily limited by membership of society and by the rights of others and the interests of the community. ${ }^{76}$

Section 5 of the NZBORA expressly states that rights may be subject to reasonable limits which can be "demonstrably justified in a free and democratic society". Furthermore, any interpretation of fundamental rights in New Zealand has always been purposive, considering the nature of the right infringed and the object behind whatever is infringing that right. ${ }^{77}$ Andrew Butler and Petra Butler note that the policy which underpins the right to freedom of expression is the promotion of democratic values. ${ }^{78}$ The mechanisms proposed to better protect mātauranga Māori would not be in breach of democratic values. This is because the misappropriation and offensive use of mātauranga Māori in the public arena does not in itself promote democratic values. Therefore, inhibiting those uses would not cause any damage to democracy. In New Zealand, freedom of expression indeed has a very wide scope as a right, ${ }^{79}$ but that does not mean it is immune from limitation in certain circumstances.

Butler and Butler also note that even the ICCPR expressly recognises limitations to freedom of expression, including racial hatred and any act that constitutes incitement to discrimination. ${ }^{80}$ Even at an international level it is recognised in explicit terms that the right to freely express does not always come at the cost of being free from racial slurs or outright discriminatory behaviour. It must also be noted that the right to be free from discrimination and the rights of minorities to enjoy their culture are both enshrined in NZBORA under ss 19 and 20 respectively. The former right to be free from discrimination would apply in prohibiting the use of mātauranga Māori which is more visually and culturally offensive. The latter right of minorities to enjoy their culture seems wider and it could be argued that it supports a wider system of mātauranga Māori protection whereby Māori can regulate the misuse of their culture (in accordance with tikanga Māori) which directly affects their right to enjoy their exclusive relationship with mātauranga as kaitiaki of that mātauranga. These rights must also be upheld and appropriately balanced against the right to freedom of expression.

It is worth comparing the way in which the United States has approached balancing freedom of expression against the right to be free from racial slurs specifically within the context of trade mark registration. Two cases solidify the United States' very staunch pro-freedom of expression approach.

76 Andrew Butler and Petra Butler The New Zealand Bill of Rights Act: A Commentary (2nd ed, LexisNexis, Wellington, 2015) at [6.5.1].

77 At [4.2.1].

78 At [13.3.1]

79 Moonen v Film and Literature Board of Review, above n 75, at [15].

80 Butler and Butler, above $n$ 76, at [13.2.6]. 
The first case, mentioned above, involved the use of the name "Redskins" by an NFL franchise. ${ }^{81} \mathrm{~A}$ group of Native Americans took a case for the name to be removed as a trade mark under the Lanham Act (US), ${ }^{82}$ which prohibited (along with other things) the use of immoral and disparaging matter in trade mark signs. The Redskins NFL franchise counter-argued that the relevant provisions of the Lanham Act unduly encroached on its First Amendment free speech rights and challenged its constitutional validity, which failed in the first instance and led to an appeal which was also unsuccessful. ${ }^{83}$ Another important fact to note here is the United States Justice Department joined the case in support of the Native American claimants, and even Barack Obama (then President of the United States) voiced his support for those claimants and encouraged the Redskins franchise to think about a name change. ${ }^{84}$

The Redskins franchise then appealed to the United States Supreme Court. However, a decision of the Supreme Court in respect of another case involving an Asian rock band called "the Slants" effectively made the case moot in favour of the franchise. ${ }^{85}$ That band was also challenging the Lanham Act, only in this case it was to have the name of their band (ironically understood to be a common racial slur derogating Asian people) registered as a trade mark in the United States. They said this was in order to re-appropriate the racial slur as their own and turn it into something positive, and the Supreme Court eventually ruled in their favour, stating that the anti-disparagement clauses within the Lanham Act were in violation of the First Amendment right to free speech, also striking down those clauses as unconstitutional. ${ }^{86}$ The Supreme Court made this decision before the Redskins case was to be decided on appeal which forced the claimants to quit their case. This also now means that the Lanham Act provisions which protect against derogatory trade mark use are redundant.

These examples from the United States run counter to the arguments made above in respect of appropriately balancing freedom of expression against stronger protections of mātauranga Māori. The stricter approach in the United States strongly favours freedom of speech especially in commercial contexts. It has been said that in the United States there is a growing "deregulatory trend" in commercial speech jurisprudence. ${ }^{87}$ However, the New Zealand approach to freedom of expression (and fundamental rights generally) is different to the United States approach. There are also important differences in that the United States has no equivalent to s 5 of the NZBORA, or any constitutional

81 Pro-Football Inc v Blackhorse, above n 17

82 Lanham Act 15 USC $\S \S 1051$.

83 Xavier Morales "A Guide to the Washington Redskins Trademark Case" (18 May 2018) SecureYourTradeMark.Com <https://secureyourtrademark.com/blog/washington-redskins>.

84 Shapira and Marimow, above n 9.

85 Matal v Tam 137 S Ct 1744 (2017).

86 "Matal v Tam" (2017) 131 Harv L Rev 243 at 243.

87 At 243 
recognition of indigenous rights or protections like the Treaty, which could explain the difference in approach. This comparison is more of a useful exercise in pointing out the extreme end of the profree speech approach which New Zealand ought to avoid in the context of offensive trade mark use. This is because such an extreme approach would create racial and social disharmony by freely allowing the use of offensive trade marks on the grounds of freedom of expression. There must be an appropriate, context-oriented and purpose promoting balance between these rights.

On the grounds outlined above, this article argues that the cultural misappropriation ground, as well as any other infringements of the right to freedom expression the Rūnanga might commit, in practice would be more than demonstrably justified in a free and democratic society. There is an appropriate balance here between the right to express freely and protecting mātauranga Māori.

\section{E Comparison of Two Proposals}

Out of the two proposals explored above, the new tikanga Māori hybrid system would be more effective in protecting mātauranga Māori. This is because it departs significantly from the current extractive model and gives life to tikanga Māori principles in settling issues that might arise from the misuse of mātauranga Māori in trade mark designs. This is a fuller recognition of tino rangatatiratanga over the use of taonga Māori, which should see greater economic prosperity among Māori communities because Māori effectively are less likely to lose out on the opportunity to capitalise on their own taonga if they so choose.

The Rūnanga system would not be restricted to the confines of the existing intellectual property regime in New Zealand and would be governed by tikanga Māori. It would not be limited to trade marks because its mana would span across all uses of mātauranga Māori, and its function would be both proactive and responsive. This would include uses whether they are put forward for any type of registration or not. The Rūnanga would also have significant powers to prohibit any misuse of mātauranga Māori which would operate over and above the intellectual property system's rules. Because the Rūnanga's primary focus would be maintaining the integrity of mātauranga Māori as a body of knowledge, it will guarantee a greater protection of specific individual, iwi and hapu interests in certain mātauranga as well as the wider general interest of te iwi Māori in other forms of mātauranga.

On balance, the tikanga Māori system administered by the Rūnanga would provide greater protection of taonga and mātauranga Māori. However, the misappropriation ground would practically be easier to implement in the short-term. It might serve as an interim protection until the Rūnanga is established. This idea is developed further below.

\section{F Whether the Two Proposals can Operate Side By Side}

The first proposed reform is a mechanism of cultural misappropriation as a new absolute ground for refusing and/or removing the registration of a trade mark right in New Zealand under the Trade Marks Act. The second proposal is Te Rūnanga o te Mātauranga, a body which would operate 
independently from (yet be empowered by) the executive government to regulate, control and protect mātauranga Māori through a forum for Māori and non-Māori, ultimately run on the basis of tikanga Māori principles.

It seems unlikely that these two mechanisms could operate concurrently in any meaningful or beneficial way. This is because the Rūnanga's tikanga system would subsume any utility of the trade mark removal ground of cultural offensiveness. Its mana would assume jurisdiction over any matter of intellectual property concerning mātauranga Māori and would most likely be more effective than that trade mark ground on its own.

However, the first mechanism of removal or refusal of a trade mark on the grounds of cultural offensiveness exemplifies the smaller steps within the system that can be taken in the interim. The Rūnanga's tikanga system would take a lot of discussion and time to prepare. The political and legislative process would require a lot of time and resourcing. Conversely, creating a new ground of trade mark removal or refusal would take far less time and effort, and would still be somewhat effective in protecting mātauranga Māori, at least in the space of trade marks. Therefore, though the two mechanisms would not operate concurrently in any effective way, they should not be viewed in isolation or as being entirely inconsistent with one another. The very reason this article offers two not entirely consistent mechanisms is to show that there are levels and stages to achieving the best form of protection of mātauranga Māori, all of which can be conducive to achieving that "middle ground" referred to above by Aroha Mead. ${ }^{88}$

\section{G Further Justification for a Tikanga Mäori System: "A Third Law"}

This part adds to the Treaty-related justifications, discussed earlier, for expressly recognising a full body of tikanga Māori as a regulator and protector of mātauranga Māori by providing further reasoning as to why such a body can and should be used. The model proposed of a tikanga Māoribased body empowered to protect mātauranga Māori within the New Zealand legal system is a manifestation of third law, the idea presented by Williams J, now a member of the Supreme Court of New Zealand. Writing extrajudicially, Williams $J$ describes the period which New Zealand law is coming into as one which represents the creation of this third law - a result of the first law (Māori law brought to Aotearoa by Kupe) and the second law (English law brought to New Zealand by Cook) converging, conflicting and finding compromise. ${ }^{89}$

There is also a growing general acceptance of Māori customary laws in New Zealand. This suggests that a new tikanga-based forum which is still empowered by, and shares similarities with, western legal mechanisms might not be as far-fetched as it would have been a few decades ago. There is an emergence and acceptance of tikanga Māori concepts and Māori laws through many different

88 Mead, above n 6, at 2.

89 Williams, above n 55, at 12. 
areas of the New Zealand legal system. There are also many legislative and judicial examples which show that, particularly in areas of law where Māori have deeply vested interests, the system is recognising the value of tikanga Māori. However, it is the extent to which tikanga affects western law which is still very much in an amorphous state.

Jacinta Ruru points to an example which she considers "particularly revolutionary", that being the negotiated co-management of New Zealand's longest river, the Waikato River, which is encapsulated in a 2010 statute which essentially reflects an agreement between the New Zealand Government and four different iwi to commit to cleaning up river pollution to a standard "that embraces Māori notions of health and wellbeing". ${ }^{90}$ Other arguably more revolutionary examples include the Crown providing for the recognition of legal personhood over natural resources such as rivers and forests and providing the iwi who are kaitiaki over those places with a significant stake in managing those taonga, in line with the tikanga of those iwi, as part of direct negotiations with the Crown to address the Crown's historical breaches of the Treaty. ${ }^{91}$

There are other examples of this third law outside of environmental protection law such as social welfare and the protection of children, as shown in the recent reforms to the Oranga Tamariki Act 1989, where terms specific to tikanga Māori have been introduced as principles to be considered when deciding cases involving Māori children. ${ }^{92}$ Furthermore, the Law Commission in 2001 expressly recognised that tikanga is law in New Zealand and that its recognition is integral to the social, economic, cultural and political development of te iwi Māori. ${ }^{93}$ The highest court of New Zealand's judiciary has also recognised on two separate occasions the value and place of tikanga Māori in the common law of New Zealand, stating that it has remained part of New Zealand law since the signing of the Treaty. ${ }^{94}$ All of these examples point to the fact that this new system to protect mātauranga Māori could be a reality in the current legal climate of New Zealand and indeed there is a growing appetite for academic discussion around how tikanga Māori and western law can appropriately coexist. The Law Commission also stated that: ${ }^{95}$

... it is critical that Māori also develop proposals which not only identify the differences between tikanga and the existing legal system, but also seek to find some common ground so that Māori development is not isolated from the rest of society.

90 Jacinta Ruru "Legal Indigenous Recognition Devices" (2016) 8(26) ILB 26 at 27.

91 Te Awa Tupua (Whanganui River Claims Settlement) Act 2017, s 12; and Te Urewera Act 2014, s 11.

92 Oranga Tamariki Act 1989, ss 2, 4, 5, 7AA and 13.

93 Law Commission Māori Custom and Values in New Zealand Law (NZLC SP9, 2001) at [76]-[79] and [402].

94 Takamore v Clarke [2012] NZSC 116, [2013] 2 NZLR 733 at [94] and [150]; and Ngāti Whätua Ōrākei Trust $v$ Attorney-General [2018] NZSC 84, [2019] 1 NZLR 116 at [71] and [77].

95 Law Commission, above n 93, at [403]. 
However, some limitations ought to be recognised as barriers to implementation. For instance, majority New Zealand resistance against a system created for the benefit of Māori. Though acceptance is growing, there may still be a long and slow road ahead in making room for tikanga Māori in the current system. Many people might also be resistant to such a significant change. However, in line with the comments made directly above, smaller incremental changes (such as the new absolute ground of cultural misappropriation to refuse trade marks proposed above) in the interim might eventually lead to non-Māori comfort with and acceptance of tikanga Māori in protecting all forms of taonga Māori. Eventually, this could then lead to the new tikanga Māori forum proposed in this article to protect mātauranga Māori. Also, the Rūnanga's primary focus would be on restoring balance and maintaining positive relationships between Māori and non-Māori parties in a way that is consistent with tikanga Māori principles. It is hoped that it will in practice serve as the connecting link between Māori and non-Māori in respect of intellectual property and mātauranga Māori and ensure a more sustainable Treaty relationship pervades the space of intellectual property in the law of New Zealand.

\section{CONCLUSION}

This article has offered two proposals with an important role in reforming and decolonising the intellectual property system in New Zealand. These proposals counter the effects of the intellectual property system as a product of the colonial model which has subjugated and disenfranchised indigenous peoples for a long time. Indigenous peoples already have their own laws and systems that regulate knowledge, but these have been unjustly subsumed by majoritarian power. It is this starting point which exposes the seriousness in addressing the issues which result from the clash in values between both worlds - the world of the coloniser and the world of the colonised. In the New Zealand context, this seriousness is reinforced by the New Zealand Government's obligations under the Treaty to actively protect mātauranga Māori as well as recognise the tino rangatiratanga of Māori over their own mātauranga. The best way to achieve this is to find a fairer middle ground between those two worlds. The cultural misappropriation mechanism and the tikanga Māori system proposed in this article, which build upon the Tribunal's Wai 262 report, are both recommendations which might go some way in achieving that middle ground. In the long-term, the latter of those proposals would be more effective and appropriate due to the elevation of tikanga Māori which has an inseparable and co-sustaining relationship with mātauranga Māori. That system is also a more direct embodiment of the tino rangatiratanga of Māori maintained by the Treaty.

These proposed mechanisms are also generally consistent with the objectives and principles of the TRIPS Agreement: as recognised by the Tribunal, "[t]he TRIPS Agreement is a floor, not a ceiling", which means extra protections can be added where suited to the domestic context. ${ }^{96}$ Human rights protections, particularly the right to freedom of expression enshrined in the NZBORA in recognition of the ICCPR, also would not stand in the way of these proposed mechanisms. This is

96 Ko Aotearoa Tēnei: Te Taumata Tuatahi, above n 27, at 51. 
because any infringement of that right is likely to be justified in a free and democratic society given the importance of the objective of protecting mātauranga Māori in Aotearoa.

Finally, New Zealand is slowly but surely moving into an era of third law, a reconciliation of Māori and western law. Areas outside of intellectual property are moving with the tide and it is time intellectual property followed, especially given the wide effect this system has on mātauranga Māori. This article has stressed the importance of innovating decolonising models which either disentangle or protect from the extractive nature of the intellectual property system to improve the protection of mātauranga Māori. It is hoped that the models proposed go some way in contributing to a way forward. 